PAWEE ŚWIETLIK'

Kielce University of Technology

VLADIMIR DEKÝS̆

University of Žilina

1e-mail: pswietlik@tu.kielce.pl

\title{
COMPARATIVE ANALYSIS OF MEASUREMENT DATA RECORDED BY TWO TRAFFIC MONITORING STATIONS
}

\section{ANALIZA PORÓWNAWCZA WYNIKÓW POMIARÓW ZAREJESTROWANYCH PRZEZ DWIE STACJE MONITORUJĄCE RUCH POJAZDÓW DROGOWYCH}

DOI: $10.30540 /$ sae-2018-017

\begin{abstract}
The paper reports statistical analysis of the data recorded by two stations monitoring traffic noise in a medium-sized city, such as Kielce. One station is located beside the national road, the other beside the provincial road. The results under analysis included the equivalent sound levels recorded in 2013. The coefficient of variation, quartile deviation and deviations from the mean were proposed for comparing the dependencies recorded.
\end{abstract}

Keywords: traffic noise, noise measurements, urban traffic

Streszczenie

$W$ artykule przedstawiono analizę statystyczna wyników pomiarów zarejestrowanych przez dwie stacje monitorujace hałas drogowy w mieście średniej wielkości takim jak Kielce. Jedna stacja znajduje się przy drodze krajowej, a druga przy drodze wojewódzkiej. Analizowane wyniki dotycza równoważnego poziomu dźwięku zarejestrowanego w roku 2013. Wspótczynnik zmienności odchylenia standardowego, odchylenie ćwiartkowe, wspótczynnik zmienności odchylenia od wartości średnich zostały zaproponowane do porównywania zarejestrowanych zależności.

Słowa kluczowe: hałas drogowy, pomiary hałasu, ruch pojazdów w mieście

\section{INTRODUCTION}

The Resolution of the European Committee on the requirement of developing, making accessible and updating noise maps has again drawn the attention of communities to environmental noise defined as a factor greatly affecting comfort of life. Noise assessment relies on short- or long-term noise indicators [1]. Acoustic measurements are made at selected sites of the assessment area and last from a few hours to several days [2]. Determining long-term indicators, which should be representative of the whole calendar year, is especially cumbersome [3]. Road traffic noise measurements and vehicle monitoring systems use permanent monitoring terminals that record the data

\section{WPROWADZENIE}

Rozporządzenie Komisji Europejskiej w sprawie obowiązku opracowania, udostępniania oraz aktualizowania map hałasu ponownie zwróciło uwagę społeczeństwa na ten czynnik, który zanieczyszcza środowisko i obniża komfort życia. Do oceny tego zjawiska wykorzystuje się wskaźniki hałasu krótko- lub długoterminowe [1]. W tym celu przeprowadzane są pomiary akustyczne w wybranych punktach badanego obszaru, których czas wykonywania najczęściej wynosi od kilku godzin do kilku dni [2]. Szczególnie kłopotliwe jest wyznaczanie wskaźników długoterminowych, które powinny być reprezentatywne dla całego roku kalendarzowego [3]. W celu monitorowania hałasu komuni- 
throughout the year [4]. Statistical analysis of these measurements is the focus of this paper.

\section{NOISE MEASURING STATIONS}

The paper reports the results of a statistical analysis of the sound level measurements recorded by permanent automatic sound and traffic volume monitoring stations in Kielce. The city of Kielce was selected as an example of a medium-sized city (with a population of about 200,000), located in the southern part of central Poland, in the margins of the Świętokrzyskie Mountains. Temperatures within a year range approximately from $-5^{\circ} \mathrm{C}$ in January to $+17^{\circ} \mathrm{C}$ in July. Average monthly precipitation is from $34 \mathrm{~mm}$ in October to $96 \mathrm{~mm}$ in July. The wind, predominantly from the south and west, reaches an average speed of about $10 \mathrm{~km} / \mathrm{h}$ over a year. Kielce gets on average 70 days a year of snow on the ground. The data under analysis were recorded by two of such stations, one located in Krakowska Road (S1) and the other in Warszawska Road (S2).

Krakowska Road, with four lanes of traffic separated by a 3-m grass median, is the major part of the Krakówbound thoroughfare functioning as both the transit route and the city street. The structural condition of the bituminous pavement is good. The noise monitoring station is located at the site with the following coordinates $50^{\circ} 51^{\prime} 37.8^{\prime \prime} \mathrm{N}$ and $20^{\circ} 35^{\prime} 41.2$ 'E. Figure 1 shows the location of the S1 station in the urban layout of Kielce. It is situated between two busy intersections but at substantial distance. Opposite the road, there is a large handball hall and the bus depot of the Municipal Public Transport Service. The database of the recorded data comprises 905 records in the form of calculated values of the equivalent sound level. Due to technical difficulties, the database covers only the period between 8 January and 6 December 2013 split into three sub-intervals of a 24 -hour interval: day time, evening time and night time.

Warszawska Road is a two-lane road out of Kielce. The function of this road has changed. It was originally designed for heavy vehicle loads. Currently, after transformation, the road is being used mainly for municipal transport and, to a slight extent, as a transit route to Warszawa. The structural condition of the bituminous pavement is good. The noise monitoring station is located at the site with the following coordinates $50^{\circ} 54^{\prime} 15^{\prime \prime} \mathrm{N}$ and $20^{\circ} 40^{\prime} 32^{\prime \prime} \mathrm{E}$. Figure 2 shows the location of the $\mathrm{S} 2$ station in the urban layout of Kielce. The measured equivalent sound level data from this station cover the period between 26-09-2012 and 12-11-2013, with the sample of 1022 records. kacyjnego drogowego oraz ruchu środków transportu budowane są w niektórych miastach systemy stacjonarnych stacji pomiarowych, rejestrujących wartości tych mezurandów przez cały rok [4]. Analiza statystyczna wyników pomiarów stacji jest celem niniejszej pracy.

\section{STACJE POMIARU HALASU}

$\mathrm{W}$ artykule przeprowadzono analizę statystyczną wyników pomiarów poziomu dźwięku pochodzących ze stacjonarnych, automatycznych stacji monitorowania poziomu dźwięku i natężenia ruchu pojazdów, znajdujących się w Kielcach. Kielce zostały wybrane jako przykładowe miasto średniej wielkości (około 200 tys. mieszkańców), położone w południowej części centralnej Polski. Miasto leży na obrzeżu Gór Świętokrzyskich. Temperatura w ciągu roku zmienia się od około $-5^{\circ} \mathrm{C}$ w styczniu do około $+17^{\circ} \mathrm{C}$ w lipcu. Średnie miesięczne opady atmosferyczne sięgają od $34 \mathrm{~mm}$ w październiku do $96 \mathrm{~mm}$ w lipcu. Średnia prędkość wiatru wynosi w ciągu roku około $10 \mathrm{~km} / \mathrm{h}$. Dominują wiatry zachodnie i południowe. Śnieg zalega przez około $70 \mathrm{dni}$ w roku. Analizowane wyniki zostały zarejestrowane przez dwie stacje znajdujące się przy ulicach Krakowskiej i Warszawskiej.

Ulica Krakowska, składająca się z czterech pasów ruchu, oddzielonych od siebie pasem zieleni o szerokości około $3 \mathrm{~m}$, stanowi główną część trasy wyjazdowej z centrum Kielc w kierunku Krakowa. Ulicą tą odbywa się zarówno ruch tranzytowy, jak i miejski. Stan techniczny nawierzchni bitumicznej jest dobry. Stacja monitorująca hałas znajduje się $\mathrm{w}$ punkcie o współrzędnych $50^{\circ} 51$ '37.8”N i $20^{\circ} 35^{\prime} 41.2$ 'E. Stacja znajduje się między dwoma skrzyżowaniami o dużym natężeniu ruchu, lecz w znacznej odległości od nich (rys. 1). Po drugiej stronie jezdni znajduje się duża hala sportowa do gry w piłkę ręczną oraz zajezdnia autobusowa Miejskiego Przedsiębiorstwa Komunikacji. Baza wyników pomiarów poziomu dźwięku została utworzona w formie wyliczonych wartości równoważnego poziomu dźwięku. Baza ta składa się z 905 zarejestrowanych danych. Z powodu różnych problemów technicznych baza obejmuje okres od 8 stycznia do 6 grudnia 2013 roku, z uwzględnieniem trzech pór doby: dnie, wieczory i noce.

Ulica Warszawska jest dwupasmową drogą wyjazdową z Kielc (rys. 2). Wcześniej z drogi tej korzystało wiele pojazdów ciężarowych. Obecnie, po modernizacji układu komunikacyjnego Kielc, przeznaczona jest głównie dla ruchu miejskiego, jak i w nieznacznym stopniu dla ruchu tranzytowego w kierunku Warszawy. Stan techniczny nawierzchni bitumicznej jest dobry. Stacja monitorująca przy ulicy Warszawskiej znajduje się 


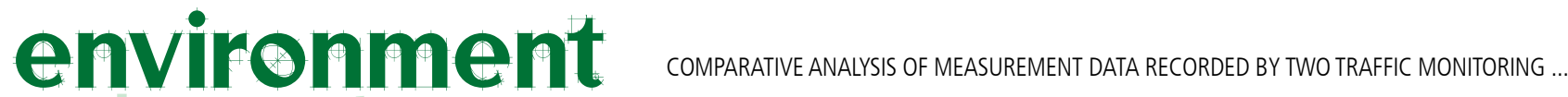

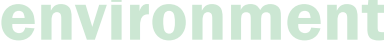

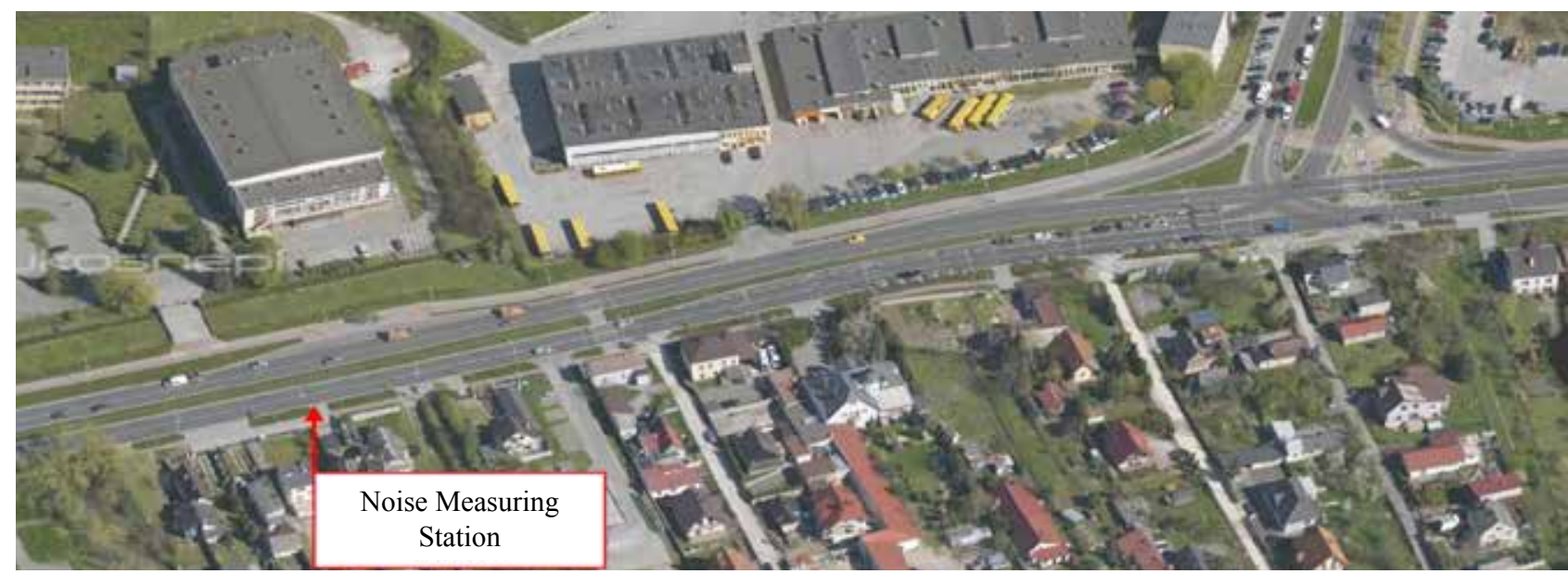

Fig. 1. Location of the noise measuring station in Krakowska Road in the urban layout of Kielce (source: Geoportal Idea Kielce) Rys. 1. Położenie stacji pomiaru hałasu przy ulicy Krakowskiej, w układzie urbanistycznym Kielc (źródto: Geoportal Idea Kielce)

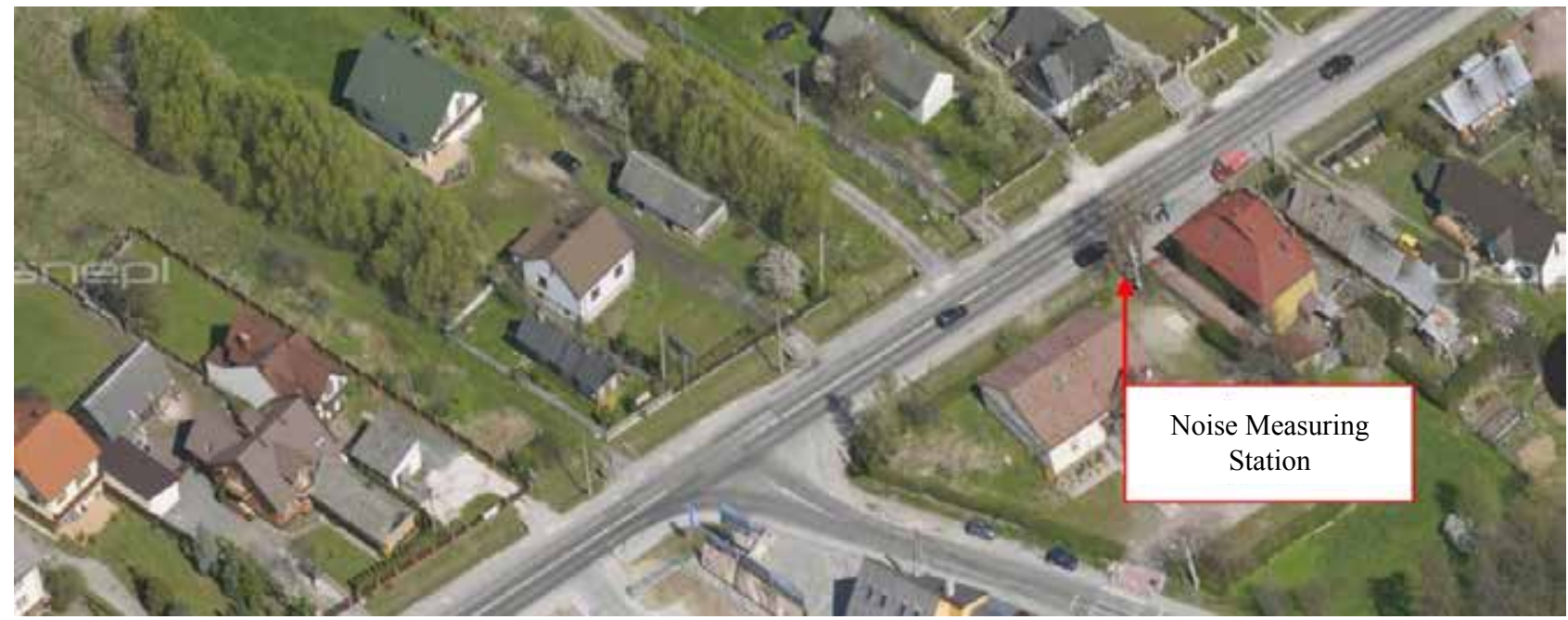

Fig. 2. Location of the noise measuring station in Warszawska Road in the urban layout of Kielce (source: Geoportal Idea Kielce)

Rys. 2. Położenie stacji pomiaru hałasu przy ulicy Warszawskiej, w układzie urbanistycznym Kielc (źródto: Geoportal Idea Kielce)

The monitoring terminals mounted in Kielce include a sound level meter, a safety camera and a weather station. The traffic volume was measured by WAVE TRONIX digital radar with an operating frequency of $245 \mathrm{MHz}$. The weather data were recorded by means of a VAISALA WTX 510 automatic weather station. The acoustic measurements were carried out using SVAN 958A device, which is a fourchannel digital vibration analyser and a class 1 sound level meter, operating within the measuring frequency range $0.5 \mathrm{~Hz}$ to $20 \mathrm{kHz}$, depending on a microphone used. The microphone for the acoustic pressure measurements is mounted at a distance of $4 \mathrm{~m}$ from the edge of the road at a height of $4 \mathrm{~m}$. The measuring microphone used in this study was a Microtech Gefell MK250 free-field, prepolarised w miejscu o współrzędnych 5054'15"N i 2040'32"E. Dane pomiarowe równoważnego poziomu dźwięku zarejestrowane przez stację obejmowały okres od 26 września 2012 do 12 listopada 2013 roku. Liczebność próby wyniosła 1022 wyników pomiarów.

Stacje monitoringu zainstalowane $\mathrm{w}$ Kielcach zawierają miernik poziomu dźwięku, radar drogowy oraz stację pogodową. Do pomiaru natężenia ruchu użyto radaru drogowego o częstotliwości roboczej $245 \mathrm{MHz}$ firmy WAVE TRONIX. Dane pogodowe zbierano za pomocą automatycznej stacji meteo VAISALA WTX 510. Pomiary akustyczne przeprowadzano przyrządem SVAN 958A, który jest czterokanałowym, cyfrowym miernikiem poziomu drgań i dźwięku klasy 1. Zakres częstotliwości pomiarowych zawiera się $\mathrm{w}$ przedziale od $0,5 \mathrm{~Hz}$ do $20 \mathrm{kHz}$, w zależności od użytego mikro- 
$1 / 2$ " condenser microphone with a sensitivity of $50 \mathrm{mV} / \mathrm{Pa}, \mathrm{SV} 12 \mathrm{~L}$ preamplifier, a frequency range $3.5 \mathrm{~Hz}$ to $20 \mathrm{kHz}$ and a dynamic range from $15 \mathrm{~dB}$ to $146 \mathrm{~dB}$. The temperature range within which the device is operable is from $-50^{\circ} \mathrm{C}$ to $100^{\circ} \mathrm{C}$. The resolution of the signal RMS detector is $0.1 \mathrm{~dB}$. The measurements were carried out 24 hours a day. The RMS values of the A sound level were registered in the buffer every $1 \mathrm{~s}$ and the results were recorded every 1 minute. The equivalent sound level was calculated on this basis for three time intervals, i.e., from 6:00 to 18:00, from 18:00 to $22: 00$ and from 22:00 to $6: 00$.

\section{MEASUREMENT RESULTS}

The authors of [4] analysed the A-weighted equivalent sound levels (denoted $L_{\text {Aeq,T }}$ ) expressed in terms of decibels, recorded by the selected stations. This parameter can be determined as follows [5]:

$$
L_{A e q, T}=10 \cdot \log \left[\frac{1}{T} \int_{0}^{T}\left(\frac{p_{A}(t)}{p_{0}}\right)^{2} d t\right]
$$

where: $p_{A}(t)$ - is the $A$-weighted acoustic pressure, $p_{0}$ - is a reference acoustic pressure, standardized as $20 \mu \mathrm{Pa}, T-$ is the entire measurement time interval.

The Shapiro-Wilk test and the Jarque-Bera test provided sufficient evidence to reject the null hypothesis about normal distribution of the data under analysis (expressed in $\mathrm{dB}$ ) at the significance level of 0.05 in all the cases considered - for the Warszawska Road site. The same tests applied to the data from the Krakowska Road site did not provide enough evidence to reject the null hypothesis in four cases: for the night time on Mondays and Thursdays and for the day time and evenings on Sundays.

The equivalent sound level can also be determined using:

$$
\begin{aligned}
L_{A e q, T} & =10 \cdot \log \left[\frac{1}{T} \sum_{i=1}^{N} t_{i} \cdot\left(\frac{p_{A i}}{p_{0}}\right)^{2}\right] \\
& =10 \cdot \log \left[\left(\frac{p_{A}}{p_{0}}\right)^{2}\right]
\end{aligned}
$$

fonu. Mikrofon do pomiaru ciśnienia akustycznego znajduje się w odległości 4 m od krawędzi jezdni i na wysokości $4 \mathrm{~m}$. W badaniach zastosowano mikrofon pola swobodnego, pojemnościowy prepolaryzowany 1/2" firmy Microtech Gefell MK250, o czułości 50 $\mathrm{mV} / \mathrm{Pa}$, wraz z przedwzmacniaczem SV 12L, zakres częstotliwości wynosi od 3,5 Hz do $20 \mathrm{kHz}$. Zakres dynamiki wynosi od $15 \mathrm{~dB}$ do $146 \mathrm{~dB}$. Przyrząd może pracować w zakresie temperatur od $-50^{\circ} \mathrm{C}$ do $100^{\circ} \mathrm{C}$. Rozdzielczość detektora parametru RMS sygnału wynosi $0,1 \mathrm{~dB}$. Pomiary prowadzono przez 24 godziny na dobę. Podczas badań rejestrowano w buforze wartość RMS poziomu dźwięku A co 1 sekundę, a wyniki zapisywano co 1 minutę. Na podstawie tych rejestracji prowadzone były obliczenia równoważnego poziomu dźwięku dla trzech przedziałów czasowych, tj. od 6:00 do 18:00, od 18:00 do 22:00 oraz od 22:00 do 6:00.

\section{WYNIKI POMIARÓW}

W pracy [4] poddano analizie wartości równoważnego poziomu dźwięku (ozn. $L_{\text {Aeq,T }}$ ) wyrażanego w decybelach, zarejestrowanego przez wybrane stacje. Parametr ten wyznaczyć można w następujący sposób [5]:

$$
L_{\text {Aeq }, T}=10 \cdot \log \left[\frac{1}{T} \int_{0}^{T}\left(\frac{p_{A}(t)}{p_{0}}\right)^{2} d t\right]
$$

gdzie: $p_{A}(t)$ - wartość ciśnienia akustycznego, skorygowana według charakterystyki częstotliwościowej $A$, $p_{0}$ - ciśnienie akustyczne odniesienia wynoszące $20 \mu \mathrm{Pa}$, $T$ - całkowity czas pomiaru.

Przeprowadzone testy statystyczne Shapiro-Wilka i Jarque-Bera pozwoliły na odrzucenie hipotezy zerowej H0 o zgodności rozkładu analizowanych danych (wyrażonych $\mathrm{w} \mathrm{dB}$ ) z rozkładem normalnym, na poziomie istotności 0,05 , we wszystkich rozważanych przypadkach - dla ulicy Warszawskiej. Analogiczne testy przeprowadzone dla danych zarejestrowanych na ulicy Krakowskiej nie dawały podstaw do odrzucenia tej hipotezy w czterech przypadkach: dla danych zarejestrowanych $\mathrm{w}$ poniedziałkowe i czwartkowe noce oraz $\mathrm{w}$ niedzielne dnie i wieczory.

Równoważny poziom dźwięku można wyznaczyć również w oparciu o następujące równanie:

$$
\begin{aligned}
L_{A e q, T} & =10 \cdot \log \left[\frac{1}{T} \sum_{i=1}^{N} t_{i} \cdot\left(\frac{p_{A i}}{p_{0}}\right)^{2}\right] \\
& =10 \cdot \log \left[\left(\frac{p_{A}}{p_{0}}\right)^{2}\right]
\end{aligned}
$$


a)
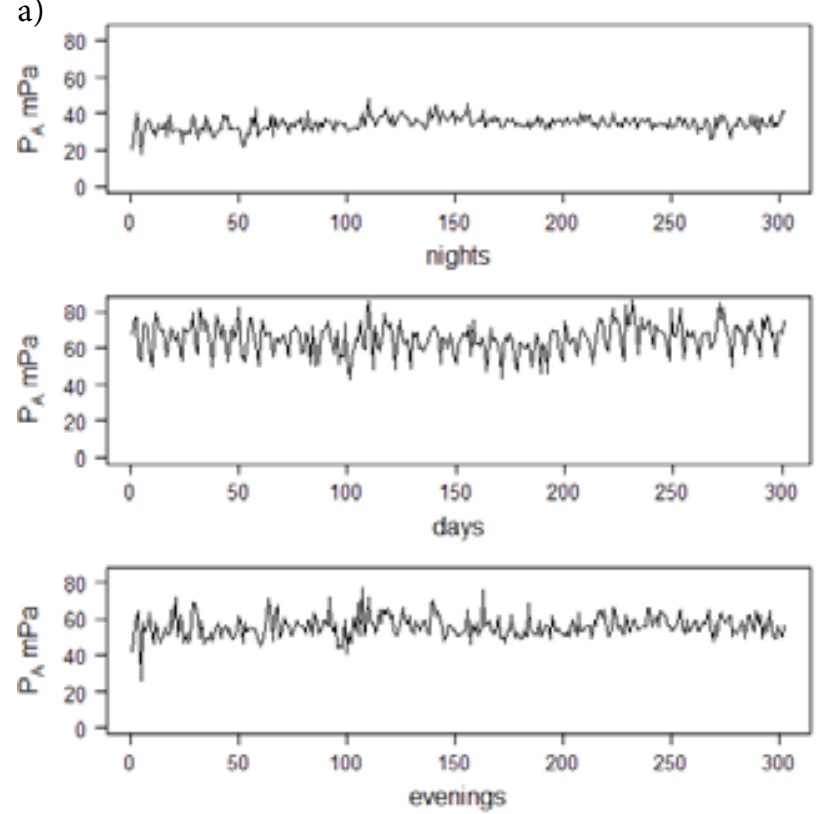

b)
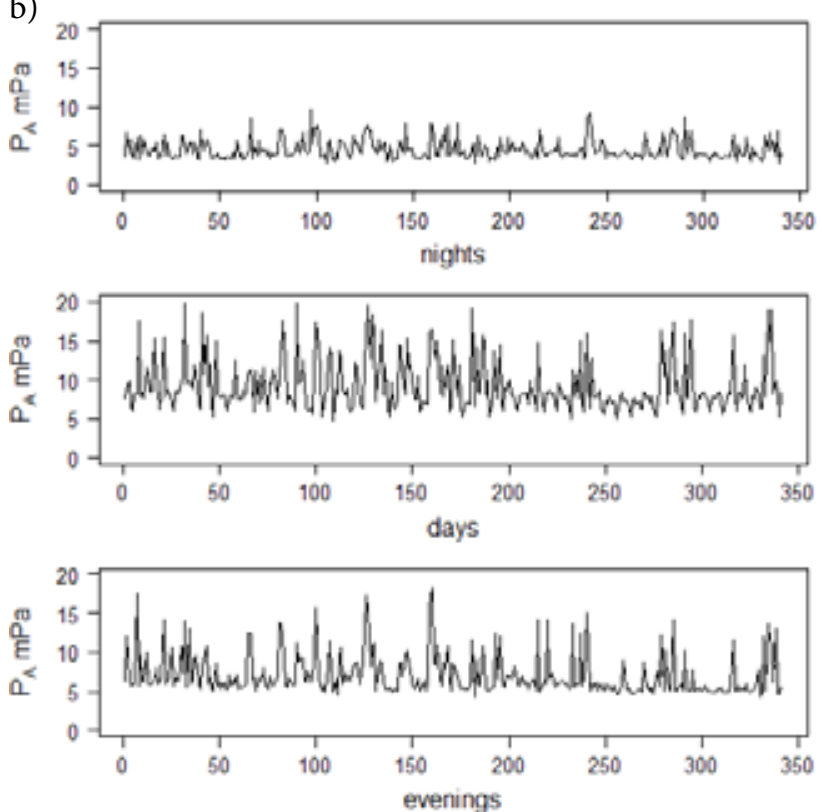

Fig. 3. Acoustic pressure changes in sub-intervals of the 24 interval for: a) Krakowska Rd, b) Warszawska Rd Rys. 3. Zmiany ciśnienia akustycznego z uwzględnieniem pory doby dla ulic: a) Krakowskiej, b) Warszawskiej
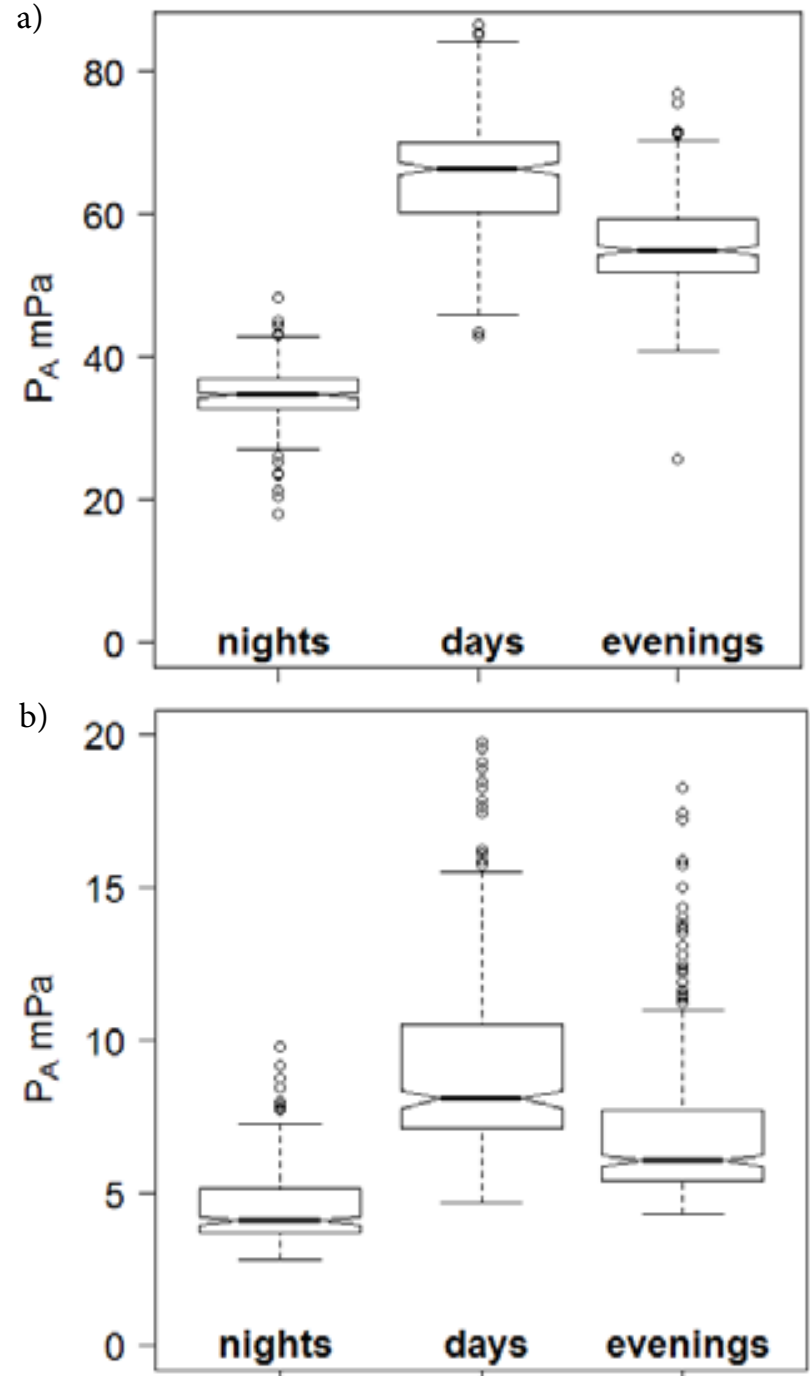

Fig. 4. Box plots of $p_{A}$ for all measurement intervals in 2013 split into sub-intervals: a) Krakowska Rd, b) Warszawska Rd Rys. 4. Wykresy pudetkowe $p_{A}$ dla wszystkich dni pomiarowych $w$ roku 2013 z uwzględnieniem pory doby: a) dla ulicy Krakowskiej, b) dla ulicy Warszawskiej 
where: $\sum_{i=1}^{N} t_{i}=T$

Equation (2) provides a possibility to determine the acoustic pressure $p_{A}$ at time interval $T$ corresponding to $N$ recorded values:

$$
p_{A}=p_{A_{R M S}}=\sqrt{10^{\left(0.1 \cdot L_{\text {Aeq }, T}\right)} \cdot p_{0}^{2}}
$$

In this study, the authors analysed the measurement data expressed in terms of $\mathrm{Pa}$ to be able to compare the fixed components (the mean and the median) and variable components (deviation from the mean) of the signals recorded.

The logarithmic scale of the equivalent sound level $\left(L_{A e q, T}\right)$ can hinder a direct comparison of the measurement results. This scale also affects the distribution of the variables and thus the ShapiroWilk and Jarque-Bera test results. This paper reports the results recorded on arbitrarily chosen days of the week (two working days, i.e., Mondays and Thursdays, and Sundays), split into three time subintervals (night time, day time and evenings).

Examples of $p_{A}$ for all measurement days in 2013, split into three time sub-intervals are shown in Figure 3.

The Shapiro-Wilk test and the Jarque-Bera test provided sufficient evidence to reject the null hypothesis about normal distribution of the data under analysis at the assumed significance level of 0.05. It follows from Figure 3 that in the case of the Krakowska Road site, parameter $p_{A}$ is substantially higher than that for the Warszawska Road site.

Analysis of the box plots in Figure 4 shows that for both roads, some data can be regarded as atypical. Because no causes were indicated for the occurrence of atypical data, these data were taken into account in further analysis of the recorded samples. A larger number of outlier data was recorded at the Warszawska Road site.

The acoustic pressure variation was determined using the coefficient of variation and quartile deviation. The coefficient can be calculated from:

$$
\operatorname{COV}_{P_{a}}=C O V=\frac{\sigma_{p_{A}}}{\overline{p_{A}}} \cdot 100 \%
$$

This coefficient is a relative, dimensionless measure of acoustic pressure dispersion. The quartile deviation was determined from: gdzie: $\sum_{i=1}^{N} t_{i}=T$

Wzór (2) daje możliwość wyznaczenia wartości ciśnienia akustycznego $p_{A}$ panującego $\mathrm{w}$ badanym okresie $T$, odpowiadającym $N$ zarejestrowanym wartościom:

$$
p_{A}=p_{A_{R M S}}=\sqrt{10^{\left(0,1 \cdot L_{\text {Aeq }, T}\right)} \cdot p_{0}^{2}}
$$

W niniejszym opracowaniu autorzy poddali analizie wyniki pomiarów wyrażone w paskalach. Uzasadnieniem tego podejścia jest zamiar porównania składowych stałych (rozumianych jako wartość średnia lub mediana) oraz składowych zmiennych (odchyłki od wartości średniej) zarejestrowanych sygnałów.

Logarytmiczna skala wartości równoważnego poziomu dźwięku ( $\left.L_{A e q, T}\right)$ może utrudniać bezpośrednie porównanie wyników pomiarów. Skala ta również ma wpływ na rozkład analizowanych zmiennych, a co za tym idzie na wyniki testów Shapiro-Wilka i Jarque-Bera. W pracy analizie poddano wyniki zarejestrowane w wybranych arbitralnie dniach tygodnia (dwa dni robocze, tj. poniedziałki i czwartki, oraz niedziele), z uwzględnieniem podziału na trzy pory doby (noce, dnie i wieczory).

Przykładowe wykresy obliczonych według zależności (3) wartości $p_{A}$ dla wszystkich dni pomiarowych w roku 2013, z podziałem na pory doby, pokazano na rysunku 3 .

Przeprowadzone testy statystyczne Shapiro-Wilka i Jarque-Bera pozwoliły na odrzucenie hipotezy zerowej H0 o zgodności rozkładu danych pomiarowych z rozkładem normalnym (na przyjętym poziomie istotności 0,05). Widać również, że w przypadku ulicy Krakowskiej parametr $p_{A}$ osiąga znacznie wyższe wartości niż dla ulicy Warszawskiej.

Analiza wykresów pudełkowych przedstawionych na rysunku 4 pokazuje, że w przypadku obu ulic wystąpiły dane, które można uznać za nietypowe. Ponieważ nie określono przyczyn występowania danych nietypowych, w dalszych badaniach były one uwzględniane w analizie zarejestrowanych prób. Większa liczba wartości odstających wystąpiła w przypadku ulicy Warszawskiej.

Do oceny zmienności wartości ciśnienia akustycznego zastosowano współczynnik zmienności odchylenia standardowego i odchylenie ćwiartkowe. Współczynnik zmienności odchylenia standardowego można wyznaczyć według następującej zależności:

$$
C O V_{P_{a}}=C O V=\frac{\sigma_{p_{A}}}{\overline{p_{A}}} \cdot 100 \%
$$

Współczynnik ten jest względną, niemianowaną miarą dyspersji ciśnienia akustycznego. Odchylenie ćwiartkowe wyznaczono natomiast jako: 


$$
Q_{31}=0.5 \cdot\left(Q_{3}\left(p_{A}\right)-Q_{1}\left(p_{A}\right)\right)
$$

Quartile deviation is an absolute but dimensional measure of acoustic pressure dispersion. The calculation results of sound pressure parameters for both roads are summarized in Tables 1 and 2 .

$$
Q_{31}=0,5 \cdot\left(Q_{3}\left(p_{A}\right)-Q_{1}\left(p_{A}\right)\right)
$$

Odchylenie ćwiartkowe jest bezwzględną, lecz mianowaną miarą dyspersji ciśnienia akustycznego. Wyniki obliczeń wartości parametrów dotyczących ciśnienia akustycznego dla ulic Krakowskiej i Warszawskiej przedstawiono w tabelach 1 i 2 .

Table 1. Parameters of acoustic pressure $p_{A}$ determined for Krakowska Rd

\begin{tabular}{|c|c|c|c|c|c|c|c|}
\hline Time interval & Med, $\mathrm{mPa}$ & Mean, mPa & $\mathrm{SD}, \mathrm{mPa}$ & COV, $\%$ & SW test & JB test & $\mathrm{Q}_{31}, \mathrm{mPa}$ \\
\hline \multicolumn{8}{|c|}{ Mondays } \\
\hline $24 \mathrm{~h}$ periods & 52.67 & 52.18 & 15.32 & 29.36 & 0.00 & 0.03 & 14.53 \\
\hline Nights & 34.48 & 33.89 & 3.59 & 10.60 & 0.20 & 0.11 & 2.15 \\
\hline Days & 68.36 & 68.19 & 7.19 & 10.54 & 0.24 & 0.70 & 3.46 \\
\hline Evenings & 53.34 & 54.89 & 5.96 & 10.86 & 0.19 & 0.21 & 3.89 \\
\hline \multicolumn{8}{|c|}{ Thursdays } \\
\hline $24 \mathrm{~h}$ periods & 55.98 & 53.85 & 15.10 & 28.03 & 0.00 & 0.01 & 14.78 \\
\hline Nights & 35.28 & 35.14 & 2.84 & 8.07 & 0.96 & 0.74 & 2.02 \\
\hline Days & 68.87 & 68.62 & 7.59 & 11.06 & 0.04 & 0.02 & 3.88 \\
\hline Evenings & 57.39 & 57.80 & 5.61 & 9.71 & 0.23 & 0.39 & 3.68 \\
\hline \multicolumn{8}{|c|}{ Sundays } \\
\hline $24 \mathrm{~h}$ periods & 50.64 & 46.07 & 11.45 & 24.85 & 0.00 & 0.00 & 10.51 \\
\hline Nights & 32.06 & 31.15 & 4.10 & 13.18 & 0.03 & 0.01 & 2.29 \\
\hline Days & 53.89 & 53.34 & 4.58 & 8.58 & 0.95 & 0.89 & 2.78 \\
\hline Evenings & 53.03 & 53.72 & 4.42 & 8.23 & 0.70 & 0.80 & 3.10 \\
\hline
\end{tabular}

Tabela 1. Wartości parametrów ciśnienia akustycznego $p_{A}$ wyznaczone dla ulicy Krakowskiej

Table 2. Parameters of acoustic pressure $p_{A}$ determined for Warszawska Rd

\begin{tabular}{|c|c|c|c|c|c|c|c|}
\hline Time interval & Med, $\mathrm{mPa}$ & Mean, $\mathrm{mPa}$ & $\mathrm{SD}, \mathrm{mPa}$ & $\mathrm{COV}, \%$ & SW test, & $\mathrm{JB}$ test & $\mathrm{Q}_{31}, \mathrm{mPa}$ \\
\hline \multicolumn{8}{|c|}{ Mondays } \\
\hline $24 \mathrm{~h}$ periods & 6.18 & 7.06 & 3.34 & 47.28 & 0.00 & 0.00 & 1.75 \\
\hline Nights & 4.01 & 4.47 & 1.15 & 25.82 & 0.00 & 0.00 & 0.52 \\
\hline Days & 8.24 & 9.65 & 3.42 & 35.39 & 0.00 & 0.00 & 1.71 \\
\hline Evenings & 5.97 & 7.04 & 2.66 & 37.76 & 0.00 & 0.00 & 1.17 \\
\hline \multicolumn{8}{|c|}{ Thursdays } \\
\hline $24 \mathrm{~h}$ periods & 6.58 & 7.33 & 3.42 & 46.57 & 0.00 & 0.00 & 1.88 \\
\hline Nights & 4.01 & 4.43 & 1.01 & 22.68 & 0.00 & 0.00 & 0.53 \\
\hline Days & 8.48 & 10.03 & 3.23 & 32.22 & 0.00 & 0.00 & 2.00 \\
\hline Evenings & 6.40 & 7.54 & 2.83 & 37.52 & 0.00 & 0.00 & 1.49 \\
\hline \multicolumn{8}{|c|}{ Sundays } \\
\hline $24 \mathrm{~h}$ periods & 5.51 & 5.79 & 2.19 & 37.91 & 0.00 & 0.00 & 0.90 \\
\hline Nights & 3.68 & 4.08 & 1.13 & 27.75 & 0.00 & 0.00 & 0.49 \\
\hline Days & 6.01 & 6.99 & 2.34 & 33.52 & 0.00 & 0.00 & 0.74 \\
\hline Evenings & 5.64 & 6.25 & 1.78 & 28.51 & 0.00 & 0.00 & 0.68 \\
\hline
\end{tabular}

Tabela 2. Wartości parametrów dotyczących ciśnienia akustycznego $p_{A}$ wyznaczone dla ulicy Warszawskiej 
Analysis of the acoustic pressure distribution in Table 1 allows the inference that for the $24 \mathrm{~h}$ interval in each case, there is sufficient evidence to reject the null hypothesis $\mathrm{HO}$ (at the significance level of 0.05 ), whereas for the sub-intervals no such evidence exists. This finding is confirmed by the limiting values of probabilities (allowing the rejection of the H0) determined based on the Shapiro-Wilk and Jarque-Bera tests, and by small differences between the expected values and medians. The results support the conclusions concerning normal distribution of the equivalent sound levels expressed in $\mathrm{dB}$, as presented in [4]. The analysis of the coefficient of variation did not allow defining clearly the sub-interval for which the variable components of the signal referred to its mean value were the lowest.

Analysis of the data in Table 2 allows the inference that in all the cases considered, there is sufficient evidence to reject the null hypothesis $\mathrm{H} 0$ (at the significance level of 0.05). The results support the conclusions concerning normal distribution of the equivalent sound levels expressed in $\mathrm{dB}$, as presented in [4]. In the case of the Warszawska Road site, the differences between the expected values and medians are greater. The lowest coefficients of variation were obtained for the data recorded at night.

The analysis of acoustic pressure deviations from the mean was performed due to difficulties in using the $C O V$ for clearly defining the sub-intervals for which its values were the lowest. The deviations can be calculated from the equation:

$$
\Delta p_{A_{i}}=p_{A i}-\overline{p_{A}}
$$

This parameter can be used for analysing the variable components of the signal. The authors of this paper decided to determine the expected value of the magnitude of these deviations (denoted $\overline{\Delta p_{A_{i}} \mid}$ ) and their root-mean-square value (denoted $R M S$ ). It has to be noted that the coefficient of variation cannot be used for this purpose because the mean value of the deviations $\overline{\Delta p_{A}}=0$.

Table 3 compiles the parameters calculated for the acoustic pressure deviations from the mean value $\Delta p_{A}$ for both locations, Krakowska Road and Warszawska Road.
Analiza wyników dotyczących rozkładów ciśnienia akustycznego przedstawionych $\mathrm{w}$ tabeli 1 prowadzi do wniosku, że dla pory-doby w każdym przypadku są podstawy do odrzucenia hipotezy zerowej H0 (na poziomie istotności 0,05 ), natomiast dla innych pór w kilku analizowanych przypadkach brak jest podstaw do odrzucenia hipotezy H0. Fakt ten potwierdzają wartości granicznych prawdopodobieństw (pozwalających na odrzucenie H0), wyznaczonych w oparciu o testy Shapiro-Wilka i Jarque-Bera, jak również niewielkie różnice między otrzymanymi wartościami oczekiwanymi i medianami. Rezultaty te potwierdzają wnioski dotyczące normalności rozkładów wartości równoważnych poziomów dźwięku wyrażonych w dB, przedstawione w pracy [4]. Analiza wartości współczynnika COV nie pozwoliła na jednoznaczne określenie pory dnia, dla której składowe zmienne sygnału, odniesione do jego wartości średniej, są najmniejsze.

Analiza danych przedstawionych $w$ tabeli 2 prowadzi do wniosku, że dla wszystkich rozważanych przypadków istnieją podstawy do odrzucenia hipotezy zerowej $\mathrm{H} 0$ (na poziomie istotności 0,05 ). Rezultaty te potwierdzają wnioski dotyczące normalności rozkładów wartości równoważnych poziomów dźwięku wyrażonych $\mathrm{w} \mathrm{dB}$, przedstawione w pracy [4]. W przypadku ulicy Warszawskiej większe są również różnice między otrzymanymi wartościami oczekiwanymi i medianami. Najmniejsze wartości współczynników $\mathrm{COV}$ otrzymano dla danych zarejestrowanych w nocy.

Ze względu na trudności związane $\mathrm{z}$ wykorzystaniem współczynnika $C O V$ do jednoznacznego wskazania pór doby, dla których osiągał on wartości najmniejsze, przeprowadzono analizę odchyłek ciśnienia akustycznego od jego wartości średniej. Odchyłki te można wyznaczyć według następującego równania:

$$
\Delta p_{A_{i}}=p_{A i}-\overline{p_{A}}
$$

Jest to parametr, który można wykorzystać do badania składowych zmiennych analizowanego sygnału. Dla tak wyznaczonych odchyłek autorzy postanowili wyznaczyć wartość oczekiwaną ich modułu (oznaczenie $\left|\Delta p_{A_{i}}\right|$ ) oraz ich wartość skuteczną (oznaczenie $R M S$ ). Nalezy zwrócić uwagę na fakt, że w przypadku analizowania odchyłek sygnału ciśnienia akustycznego od jego wartości średniej nie można wykorzystać współczynnika $C O V$, ponieważ wartość średnia odchyłek $\overline{\Delta p_{A}}=0$.

W tabeli 3 przedstawiono wartości parametrów wyznaczonych dla odchyłek ciśnienia akustycznego od jego wartości średniej $\Delta p_{A_{i}}$ dla ulic Krakowskiej i Warszawskiej. 
Table 3. Parameters of acoustic pressure deviations from the mean determined for Krakowska and Warszawska roads, split into measurement intervals

Tabela 3. Wartości parametrów dotyczacych odchyłek ciśnienia akustycznego od wartości średnich w poszczególnych porach wyznaczone dla ulic Krakowskiej $i$ Warszawskiej

\begin{tabular}{|c|c|c|c|c|c|c|}
\hline Time interval & Med, $\mathrm{mPa}$ & $\Delta p_{A_{i}} \mid, \mathrm{mPa}$ & $\mathrm{RMS}, \mathrm{mPa}$ & Med, $\mathrm{mPa}$ & $\Delta p_{A_{i}} \mid, \mathrm{mPa}$ & $\mathrm{RMS}, \mathrm{mPa}$ \\
\hline Mondays & \multicolumn{3}{|c|}{ Krakowska } & \multicolumn{3}{|c|}{ Warszawska } \\
\hline $24 \mathrm{~h}$ periods & 0.49 & 13.13 & 15.26 & -0.88 & 2.49 & 3.32 \\
\hline Nights & 0.59 & 2.73 & 3.55 & -0.46 & 0.85 & 1.14 \\
\hline Days & 0.17 & 5.18 & 7.10 & -1.41 & 2.62 & 3.38 \\
\hline Evenings & -1.56 & 4.85 & 5.89 & -1.07 & 2.02 & 2.63 \\
\hline \multicolumn{7}{|l|}{ Thursdays } \\
\hline $24 \mathrm{~h}$ periods & 2.13 & 13.12 & 15.04 & -0.75 & 2.60 & 3.40 \\
\hline Nights & 0.14 & 2.27 & 2.81 & -0.42 & 0.79 & 1.00 \\
\hline Days & 0.25 & 5.35 & 7.50 & -1.55 & 2.62 & 3.20 \\
\hline Evenings & -0.41 & 4.60 & 5.55 & -1.14 & 2.20 & 2.80 \\
\hline \multicolumn{7}{|l|}{ Sundays } \\
\hline $24 \mathrm{~h}$ periods & 4.57 & 10.07 & 11.40 & -0.28 & 1.48 & 2.19 \\
\hline Nights & 0.92 & 3.10 & 4.06 & -0.40 & 0.82 & 1.12 \\
\hline Days & 0.55 & 3.58 & 4.52 & -0.98 & 1.75 & 2.32 \\
\hline Evenings & -0.69 & 3.54 & 4.37 & -0.62 & 1.20 & 1.77 \\
\hline
\end{tabular}

In the case of Warszawska $\mathrm{Rd}$, the deviations from the mean were noticeably lower. Among the three acoustic pressure deviation parameters shown in Table 3, the highest variation for different time intervals was observed in the RMS value. It has to be noted that here, the RMS value was the same as that of the loaded estimator of standard deviation. The highest RMS values for all the time intervals studied were obtained for the daytime data.

\section{CONCLUSIONS}

Analysis of the results obtained for the distribution of acoustic pressure, expressed in terms of $\mathrm{Pa}$ or $\mathrm{dB}$, in Krakowska Rd leads to the conclusion that for the 24-hour interval, there are grounds to reject the null hypothesis in each case analysed (at the significance level of 0.05 ), whereas no grounds were found to reject the $\mathrm{H} 0$ in the case of the sub-intervals. This finding is confirmed by the limiting values of probabilities (that allow the rejection of the $\mathrm{H} 0$ ) determined based on the Shapiro-Wilk and Jarque-Bera tests and by slight differences between the expected values and medians. In the case of Warszawska Road, there is enough evidence to reject the $\mathrm{HO}$ in all the cases under analysis.

The coefficient of variation is a parameter that satisfactorily describes a variable component of an
Znacznie mniejsze wartości odchyłek ciśnienia akustycznego od jego wartości średniej otrzymano w przypadku ulicy Warszawskiej. Spośród trzech parametrów sygnału odchyłek ciśnienia akustycznego przedstawionych w tabeli 3 najbardziej zróżnicowane wartości dla różnych pór-doby ma wartość skuteczna sygnału. Warto zwrócić uwagę, że w rozważanym przypadku wartość parametru RMS jest taka sama jak obciążonego estymatora odchylenia standardowego. Największe wartości parametru RMS dla wszystkich analizowanych pór doby uzyskano dla danych zarejestrowanych dla pory-dnie.

\section{WNIOSKI}

Analiza wyników dotyczących rozkładów wartości ciśnienia akustycznego wyrażonego w paskalach lub decybelach, przy ulicy Krakowskiej, prowadzi do wniosku, że dla pory-doby w każdym przypadku są podstawy do odrzucenia hipotezy zerowej H0 (na poziomie istotności 0,05 ), natomiast dla innych pór w kilku analizowanych przypadkach brak jest podstaw do odrzucenia tej hipotezy. Fakt ten potwierdzają wartości granicznych prawdopodobieństw (pozwalających na odrzucenie H0) wyznaczonych w oparciu o testy Shapiro-Wilka i Jarque-Bera, jak również niewielkie różnice między otrzymanymi wartościami oczekiwanymi i medianami. W przypadku ulicy War- 
acoustic pressure signal. This coefficient is not suitable for analysing deviations of the variable from its mean. The use of the median for determining coefficients of variation seems to be an option worth considering. For analysis of acoustic pressure deviations from the mean, the RMS value can be successfully used. szawskiej we wszystkich badanych przypadkach są podstawy do odrzucenia hipotezy zerowej $\mathrm{H} 0$.

Parametrem zadowalająco opisującym składową zmienną sygnału ciśnienia akustycznego jest współczynnik $C O V$. Współczynnik ten nie nadaje się do analizy odchyłek analizowanej zmiennej od jej wartości średniej. Można jednak rozważyć wykorzystanie do wyznaczania współczynników $C O V$ odchyłek ich medianę. W przypadku analizy odchyłek ciśnienia akustycznego od wartości średniej ich zmienność dobrze opisuje parametr $R M S$.

\section{References}

[1] Batko W., Stępięn B., Type A Standard Uncertainty of Long-Term Noise Indicator, “Arch. Acoust.”, Vol. 39, Issue 1, 2014, pp. 25-36, DOI: 10.2478/aoa-2014-0004.

[2] Gardziejczyk W., Motylewicz M., Noise level in the vicinity of signalized roundabouts, "Transportation Research Part D: Transport and Environment", Volume 46, July 2016, pp. 128-144, DOI :10.1016/j.trd.2016.03.016.

[3] Przysucha B., Batko W., Szeląg A., Analysis of the Accuracy of Uncertainty Noise Measurement, "Arch. Acoust.", Vol. 40, No. 2, 2015, pp. 183-189, DOI: 10.1515/aoa-2015-0020.

[4] Bąkowski A., Radziszewski L., Skrobacki Zb., Assessment of uncertainty in urban traffic noise measurements, "Procedia Engineering 177", Vol. 177, 2017, pp. 281-288.

[5] Wszołek T., Kłaczyński M., Effect of traffic noise statistical distribution on Laeq,T measurement uncertainty, “Arch. Acoust.", Vol. 31, Issue 4 (Supplement), 2016, pp. 311-318.

Acknowledgments:

This work was supported by Kielce University of Technology, Grant No. 01.0.04.00/2.01.01.01.0019 MNSP.MKME.17.001

\section{Podziękowania:}

Praca byta finansowana przez Politechnikę Świętokrzyska, grant nr 01.0.04.00/2.01.01.01.0019 MNSP.MKME.17.001 